\title{
DAMPAK PERUNDUNGAN ANAK YANG MEMILIKI SAUDARA KANDUNG (SIBLING)
} DISABILITAS GANDA

\author{
Oleh \\ Hastin Trustisari ${ }^{1)}$ \& Mari Esterilita ${ }^{2)}$ \\ ${ }^{1,2}$ Prodi Kesejahteraan Sosial Fakultas Ilmu Sosial dan Humaniora Universitas Binawan \\ Email: $\underline{\text { hastin@binawan.ac.id }}$
}

\begin{abstract}
This article is a research focusing on bullying experienced by siblings as a result of having family members with multiple disabilities. This research is a case study of siblings whose family members attend SLBG (Special School for Multiple Disabilities) Rawinala East Jakarta. Bullying does not only encounter people with disabilities, but also their siblings. The limitations possessed by people with multiple disabilities are often concerned and treated differently by family members and the community. Living together with people who have double disabilities as siblings is a challenge that creates particular vulnerability among siblings themselves. This vulnerability is influenced by how parents and the surroundings understand children with disabilities and their siblings. Having siblings with multiple disabilities could cause bullying. The purpose of this research is to identify forms of bullying received by teenagers who have siblings with multiple disabilities along with the impact of the bullies . This qualitative research is descriptive study in which the informants are selected by using purposive sampling. Data collection techniques used for this research involved observation, interview, FGD, and documentation. The data processing is conducted in several stages: data reduction, data presentation, and conclusion and data verification. The results of this study indicate that teenagers who experience bullying have certain acceptance reactions towards their siblings with disabilities. This condition causes siblings with disabilities feel ashamed, unconfident, thus it impacts their relationship with both their aforementioned siblings with multiple disabilities and the community. Supports from family and the surroundings are urgently needed to overcome the impact of bullying.
\end{abstract}

Keywords: Bullying, Siblings With Multiple Disabilities \& Support

\section{PENDAHULUAN}

Sepanjang tahun 2018 Komisi Perlindungan Anak Indonesia (KPAI) mencatat kasus pelanggaran hak anak mencapai 4.885 kasus. Kasus-kasus pelanggaran yang diterima oleh KPAI dalam kurun waktu tahun 2019 (Bulan Januari hingga April) didominasi oleh perundungan atau bullying berupa kekerasan fisik, kekerasan psikis, dan kekerasan seksual (www.kpai.go.id). SLBG (Sekolah Luar Biasa Ganda) Yayasan Dwituna Rawinala merupakan lembaga pendidikan yang memberikan layanan pendidikan, dan pengasuhan khusus kepada penyandang disabilitas ganda dengan kecacatan utama pada mata dengan disertai dengan kecatatan lainnya. Berdasarkan Data bulan Juni 2019, terdapat 60 anak yang mendapat layanan

http://ejurnal.binawakya.or.id/index.php/MBI pendidikan, teridentifikasi $90 \%$ diantaranya memiliki sibling (kakak/adik saudara kandung).

Penelitian ini dikembangkan dari penelitian sebelumnya yang lebih banyak berfokus pada kasus bully/ perundungan yang dialami oleh penyandang disabilitas baik disekolah, rumah, maupun di lingkungan masyarakat.

Kehadiran seseorang dengan disabilitas ganda dalam keluarga menjadi tantangan tersendiri. Pengalaman keluarga yang memiliki anggota keluarga dengan disabilitas ganda menjadi pengalaman yang luar biasa dan berdampak kepada seluruh anggota keluarga salah satunya saudara kandung. Bagi keluarga maupun saudara kandung, memiliki anggota keluarga disabilitas dalam keluarga akan memberikan pengalamam sendiri yang tidak dapat terlupakan bagi setiap anggota keluarga.

Vol.15 No.5 Desember 2020 
Pengalaman tersebut dapat merupakan pengalaman yang positif dan negative yang dapat mempengaruhi karakterstik relasi dan pola kehidupan di masa perkembangan seseorang. Hubungan saudara kandung seperti kakak dan adik merupakan hubungan yang alami, unik dan berjangka panjang. Relasi yang terbangun pada saudara kandung akan berlangsung lama dan bertumbuh sesuai dengan tahap perkembangan masing-masing anggota keluarga, sehingga kekuatan relasi yang terbangun antar sibling dalam keluarga dapat menjadi menjadi pengalaman yang tidak mudah terlupakan, baik pengalaman yang menyenangkan maupun tidak menyenangkan. Kehangatan pola hubungan antar sibling dalam keluarga tetap akan terjalin, meskipun terjadi konflik (Stefani, 2014).

Seiring waktu, dinamika sosial antar sibling dapat menumbuhkan satu ikatan yang kuat yang terjalin antar individu dan dalam waktu lain saudara kandung dapat bertindak menjadi pengganti orangtua, teman, sahabat dan juga guru infomal (Caroli, et all, 2012). Hal ini menyebabkan keluarga yang memiliki anak disabilitas, terutama disabilitas ganda memiliki kerentanan ganda. Keterbatasan yang dimiliki oleh anak disabilitas ganda, seringkali menimbulkan dampak fisik, psikologis, ekonomi, sosial bagi keluarga yang merawat dan mendampinginya. Mereka memerlukan pengasuhan dan pendampingan seumur hidupnya. Kondisi ini jelas memerlukan perhatian dan perlakukan khusus bagi seluruh anggota keluarga tak terkecuali sibling. Keterbatasan yang dimiliki penyandang disbilitas ganda pada akhinya dapat membawa sibiling pada kondisi harus menerima dan menyesuaikan diri. Tantangan-tantangan kedepan akan sering dihadapi bagi sibling dengan disabilitas pada peristiwa yang akan datang karena perbedaan perilaku dan kondisi dari saudaranya (Simatupang, 2015).

Kondisi anak dengan keterbatasan tersebut, memberikan dampak pada fungsi keluarga, termasuk pada saudara kandungnya (Hidayanti $\mathrm{N}, 2018$ ). Hal ini akan menimbulkan tekanan dan tantangan sendiri. Bagi keluarga yang memiliki

Vol.15 No.5 Desember 2020 anak atau saudara kandung dengan disabilitas, situasi ini dapat menjadi peristiwa yang traumatis tersendiri (Simatupang, 2015). Pada tahap perkembangan yang dilalui seseorang yang memiliki saudara kandung normal (Sibling) dan yang memiliki adik atau kakak penyandang disabilitas ganda dalam bertumbuh bersama dalam keluarga akan membawa pada pengalaman yang berbeda beda dalam menjalin hubungan persaudaraanya ( Nurmaningtyas,2013). Sibling memiliki kontribusi besar dalam penerimaan dan pemberi bantuan pada disabilitas ganda yang akan banyak membutuhkan bantuan sepanjang hidupnya. Sementara sibling dengan disabilitas seringkali tersisihkan dalam hal perhatian. Dalam proses ini, saudara kandung juga harus dipertimbangkan sama seperti orangtua. Ini merupakan situasi yang sulit bagi seorang anak untuk memiliki saudara yang disabilitas (Aytekin, 2016).

Keluarga yang memiliki anggota keluarga dengan disabilitas tunggal terlebih lagi dengan disabilitas ganda, memiliki kecenderungan menyembunyikan keberadaannya agar tidak diketahui oleh masyarakat bahkan keluarga besar sendiri dengan berbagai alasan, antara lain malu, dianggap pembawa sial, takut diketahui orang lain, tidak tahu harus dibawa kemana, dianggap sebagai karma, takut dibullly, dijauhi, dan takut didiskriminasi, oleh masyarakat karena keberadaan anggota keluarga yang disabilitas. Berbagai stigma, diskriminasi, pengucilan, perubahan pola perilaku dan relasi antar anggota yang muncul baik dikeluarga maupuan masyarakat merupakan bentuk dampak yang dirasakan oleh keluarga. Karakteristik tertentu yang nampak dari seseorang dapat memunculkan bentuk reaksi atau respon sosial yang negative dari orang lain yang mengarah pada stigmatisasi terutama jika dibawa di ruang publik (Devina,2018).

Bully/ Perundungan merupakan salah satu tantangan yang dihadapi oleh seseorang yang memiliki sibiling penyandang disabilitas ganda. Kasus bully/perundungan, tidak berhenti pada penyandang disabilitas saja, namun pada saudara kandungnya (siblingnya). Seringkali sibling http://ejurnal.binawakya.or.id/index.php/MBI 
merasa malu memiliki kakak/adik penyandang disabilitas ganda karena menerima bully dari lingkungan, baik sekolah maupun lingkungan tempat tinggalnya. Sehingga sibling merasa tidak percaya diri, merasa malu, marah pada sibling yang memiliki disabiltas dan adanya keengganan mendampingi saudara kandungnya untuk berjalan jalan ke luar rumah. Kate (2004) dalam buku Sibling: Brother and Sisters of Children with Special Needs, menyatakan sebuah pandangan seorang saudara penyandang disabilitas bahwa dirinya sempat merasa terisolasi dan tersingkirkan.

Sebagaimana diketahui bahwa masa perkembangan remaja digambarkan sebagai masa yang menentukan kehidupan dimasa depan. Masa remaja berhubungan dengan perilaku dan aktivitas yang dilakukan pada masa awal perkembangan, sehingga sangat menentukan di masa depan (Hurlock 2009: 207). Sehingga bagi remaja yang mengalami perundungan akibat memiliki saudara kandung dengan disabilitas ganda akan membutuhkan dukunganyang tepat untuk memastikan baik secara emosional dan sosial serta mempertahankan hubungan dengan saudara kandungnya tetap terjaga dengan baik. Hal ini menjadi penting dilakukan dengan harapan dapat mencegah trauma dan perlakuan yang negative baik kepada dirinya sendiri maupun kepada anggota keluarga dengan disbilitas ganda. Berdasarkan penelitian Lince Siringo (2014) menyatakan bahwa Saudara kandung (sibling) dari anak penyandang disabilitas fisik dan atau intelektual merupakan anak yang rentan terhadap berbagai masalah baik fisik, psikis dan atau sosial. Hadirnya anak yang menyandang disabilitas intelektual dapat mempengaruhi secara positif dan ataupun negative kehidupan dari saudara kandungnya. (Shanti, 2018). Munculnya stigma, diskriminasi, pengucilan, perubahan pola perilaku dan relasi antar anggota adalah salah satu bentuk dampak yang dirasakan oleh keluarga atas keberadaan penyandang disabilitas ganda. Salah satu bentuk rekasi dan respon sosial yang muncul adalah stigmatisasi karena adanya karakteristik tertentu (Devina, 2018).

http://ejurnal.binawakya.or.id/index.php/MBI
Dukungan sosial diperlukan untuk seluruh anggota keluarga terutama sibling remaja yang akan melewati masa-masa perkembangan dengan anggota keluarganya dengan disabilitas ganda. Beberapa manfaat dukungan sosial (Johnson \& Johnson,1991) antara lain dukungan sosial dihubungkan dengan peningkatan kesejahteraan psikologis dan penyesuaian diri dengan rasa memiliki, memperjelas tentang identitas diri,menambah harga diri serta mengurangi stress, serta dapat meningkatkan dan memelihara kesehatan fisik dan tekanan baik dari dalam maupun dari luar. Dukungan sosial keluarga yang tepat menjadi penting untuk diberikan suadara kandung yang mengalami perundungan akibat memiliki anggota keluarga disbilitas ganda. Namun seringkali orangtua hanya berfokus perhatian pada anggota keluarga yang memiliki disabilitas ganda dalam hal pendampingan, perawatan dan perhatian di banding dengan anggota lain yang tidak memiliki hambatan / kedisabilitasan . Penelitian ini ingin melihat bentuk perundungan dan dukungan apa yang dapat diberikan bagi korban perundungan dengan latar belakang kehadiran sibling dengan disabilitas di keluarga. Fokus pada saudara kandung normal yang mengalami perundungan di pilih dalam penelitian ini, karena dampaknya dikhwatirkan akan memiliki pengaruh jangka panjang terkait dengan sikap, perilaku yang dimunculkan, rasa memiliki dan kasih sayang kepada saudara kandung dengan penyandang disabilitas.

\section{LANDASAN TEORI}

\section{Pengertian Perundungan (Bullying)}

Ken Rigby dalam Zakiyah, dkk (2017), perundungan adalah sebuah hasrat untuk menyakiti. Hasrat ini diperlihatkan ke dalam aksi, menyebabkan seseorang menderita. Aksi ini dilakukan secara langsung oleh seseorang atau sekelompok yang lebih kuat, tidak bertanggung jawab, biasanya berulang, dan dilakukan dengan perasaan senang. Istilah bullying kemudian digunakan untuk menunjuk perilaku agresif seseorang atau sekelompok orang yang dilakukan secara berulang-ulang terhadap orang atau

Vol.15 No.5 Desember 2020

\section{Open Journal Systems}


sekelompok orang lain yang lebih lemah untuk menyakiti korban secara fisik maupun mental (Prasetyo, Ahmad (2011:19)

\section{Bentuk -bentuk perundungan /bullying}

Bullying bisa berupa kekerasan dalam bentuk fisik (misalnya: menampar, memukul, menganiaya, mencederai), verbal (minsal : mengejek, mengolok-olok, memaki) dan mental/ psikis (minsal : memalak, mengancam, mengintimidasi, mengucilkan) atau gabungan dair ketiganya (Ahmad Baliyo:2011). Sedangkan Riauskina, dkk (2005, dalam Ariesto, 2009) mengelompokkan perilaku bullying ke dalam 5 kategori, yaitu: a) Kontak fisik langsung (memukul, mendorong, menggigit, menjambak, menendang, mengunci, seseorang dalam ruangan, mencubit, mencakar, juga termasuk memeras dan merusak barang-barang yang dimiliki orang lain); b) Kontak verbal langsung (mengancam, mempermalukan, merendahkan (put down), mengganggu, member panggilan nama (name - calling), sarkasme, mencela/mengejek, memaki, menyebarkan gosip); c) Perilaku non verbal langsung (melihat dengan sinis, menjulurkan lidah, menampilkan ekspresi muka yang merendahkan, mengejek, atau mengancam, biasanya disertai oleh bullying fisik atau verbal); 4)Perilaku nonverbal tidak langsung (mendiamkan seseorang, memanipulasi persahabatan sehingga retak, sengaja mengucilkan atau mengabaikan, mengirimkan surat kaleng); e) Pelecehan seksual (kadangkadang dikategorikan perilaku agresi fisik atau verbal).

\section{Sibling Penyandang Disabilitas Ganda}

Sibling dapat diartikan dengan saudara kandung. Menurut Kamus Besar Bahasa Indonesia penyandang diartikan dengan orang yang menyandang (menderita) sesuatu. Sedangkan disabilitas merupakan kata bahasa Indonesia yang berasal dari kata serapan bahasa Inggris disability (jamak: disabilities) yang berarti cacat atau ketidakmampuan. Undangundang No 8 Tahun 2016 tentang Penyadang Disabilitas (Pasal 4) Penyandang Disabilitas Ganda atau multi adalah Penyandang Disabilitas yang mempunyai dua atau lebih ragam disabilitas, anatara lain disabilitas runguwicara dan disabilitas netra-tuli. Menurut Juang (2010:165) tuna ganda adalah orang yang memiliki dua atau lebih hambatan, misalnya tunanetra dan tunarungu yang disebut tunanetrarungu yang disebut tunanetra-rungu atau buta tuli.

\section{Dukungan Sosial}

Menurut Rock (dalam Kumalasri dan Ahayani, 2012: 25) dukungan sosial merupakan salah satu fungsi ikatan social yang menggambarkan tingkat kualitas umum dari hubungan interpersonal. Sarason (dalam Ajami\& Soeharto, 2014: 183) mengemukakan bahwa dukungan social adalah keberadaan, kesediaan, kepedulian dari orag-orang yang dapat diandalkan, menghargai dan menyayangi. Jiao, Heyne dan Lam (2012) juga mengemukakan bahwa selama individu dengan disabilitas mendapat dukungan dari keluarga dan teman mereka, mereka akan dengan mudah menyesuaikan diri dengan kekurangannya. Dalam montek ini, penulis ingin menghungkan kebutuhan dukungan sosial yang tepat untuk sibling remaja penyandang disabilitas ganda yang menjadi korban perundungan dan juga lingkungan lain yang saling mendukung, misalnya keluarga, lingungan sekolah, mayaralat, dll. Kuntjoro (dalam Aziz \& Fatma, 2013: 150) menyatakan bahwa dukungan sosial adalah keberadaan, kesediaan, kepedulian umtuk memberi kenyamanan, perhatian, penghargaan atau menolong orang dengan sikap menerima kondisinya.

Sarafino (dalam Maslihah, 2012: 25) membagi dukungan sosial dalam lima bentuk, sebagai berikut:

1. Dukungan Instrumental (instrumental support)

Dukungan ini meliputi penyediaan dukungan fisik atau jasmaniah seperti pelayanan, bantuan finansial dan material berupa bantuan nyata yang diperlukan oleh orang lain, seperti seseorang yang memberi makanan, atau meminjamkan uang, mengajak jalan-jalan atau rekreasi, membantu pekerjaan sehari-hari, menyampaikan pesan, menyediakan transportasi, menjaga dan

http://ejurnal.binawakya.or.id/index.php/MBI 
merawat saat sakit ataupun meminjamkan alat bantu missal kendaraan, dan kebutuhan lainnya.

2. Dukungan Informasional (informational support)

Jenis dukungan ini meliputi jaringan komunikasi dan tanggung jawab bersama, misalkan memberikan solusi dari masalah, memberikan nasehat, pengarahan, saran, memberikan informasi rujukan atau umpan balik tentang apa yang dilakukan oleh sibling disabilitas ganda .

3. Dukungan emosi (emotional support)

Dukungan emosi intinya refleksi kasih sayang yang membuat perasaan nyaman, merasa dicintai, bantuan dalam bentuk semangat, empati, rasa percaya dan perhatian. Pentingnya dukungan emosi dari orang-orang terdekat akan membantu memulihkan tingkat kepercayaan diri sibling remaja penyandang disabilitas ganda sehingga akan membuat mereka merasa aman, nyaman dan menumbuhkan kembali semangat hidup dan rasa percaya diri serta mampu mengurangi tingkat emosidan kesedihan pada sibling itu sendiri.

4. Dukungan pada harga diri (esteem support)

Dukungan ini memberikan penghormatan yang positif, memberikan pernyataan setuju, pujian dan penilaian positif terhadap ide-ide, perasaan dan penampilan penyandang disabilitas. Dukungan pada harga diri ditujukan untuk menghargai martabat sibling penyandang disabilitas ganda sebagai manusia yang memiliki kesetaraan dalam pemenuhan hak-hak.

5. Dukungan dari kelompok sosial/lingkungan (support from social group)

Dukungan ini dilakukan dengan memberikan kesempatan antar individu berkumpul dan saling mensuport satu dengan lainnya. Dukungan kelompok ini membuat individu merasa diterima, senasib dan menjadi bagian komunitas yang saling menguatkan.

\section{METODE PENELITIAN}

Penelitian ini bertujuan untuk melihat apa saja bentuk bullying yang diterima sibling remaja yang memiliki saudara penyandang disabilitas ganda dan dampak apa yang timbulkan, sehingga peneliti dapat mengetahui apa bentuk dukungan http://ejurnal.binawakya.or.id/index.php/MBI sosial yang paling tepat diberikan. Penelitian ini menggunakan desain penelitian kualitatif jenis studi deskriptif. David William (dalam Moleong, 2013:5) menulis bahwa penelitian kualitatif adalah pengumpulan data pada suatu latar ilmiah, dengan menggunakan metode alamiah, dan dilakukan oleh orang atau peneliti yang tertarik secara alamiah. Penetapan informan dengan cara pengambilan sampel menggunakan Sampling purposive. Infoman yang dipilih dengan kriteria: (1) usia remaja 12-18 tahun (2) memiliki saudara kandung disabilitas ganda (dengan kecacatan utama pada mata) sedang bersekolah di SLBG (Sekolah Luar Biasa Ganda) YPD Rawinala Kramatjati Jakarta Timur (3) tinggal dalam satu rumah (4) memiliki orang tua lengkap (ayah dan ibu).

Pada penelitian ini menemukan 8 informan kunci yaitu EL, EM, DS,MK,TL, JK, TL dan DW dan 7 infoman tambahan. Data Informan kunci diperoleh dari hasil konseling keluarga yang dilakukan oleh Pekerja Sosial Sekolah Luar Biasa Ganda Rawinala. Informan kunci merupakan remaja yang tinggal satu rumah yang mengalami perundungan akibat memiliki sibling penyandang disabilitas ganda yang sedang bersekolah di SLBG Rawinala. Keterangan Informan kunci dijadikan dasar oleh peneliti untuk dilakukan wawancara dan FGD termasuk menentukan informan tambahan lain yang diperlukan untuk mendukung keterangan. 7 Orang infoman tambahan terdiri dari orang tua, Guru BP dan Pekerja Sosial.

Pada awalnya teknik pengumpulan data yang gunakan adalah observasi, wawancara dan FGD langsung dan dokumentasi. Situasi Covid-19, peneliti tidak memungkinkan melakukan wawancara dan FDG langsung kepada seluruh informan. $70 \%$ wawancara dan FGD untuk infoman kunci dilakukan secara online, 30\% dilakukan dengan wawancara langsung yang dilakukan dengan kunjungan rumah dengan mematuhi memenuhi protocol Covid-19. Sementara untuk infoman tambahan, penggalian infomasi dilakukan dengan cara wawancara mendalam melalui sambungan telepon dan juga pertemuan virtual. Hal ini dilakukan dengan

Vol.15 No.5 Desember 2020 
mempertimbangkan pemenuhan tujuan penelitian dan kesediaan / persetujuan informan. Analisis data pada penelitian ini dilakukan melalui beberapa tahapan: Pertama, data yang diperoleh melalui observasi dan wawancara dilengkapi, diperbandingkan dan diuji dengan beberapa keterangan informan lain. Kedua, kategoritersebut kemudian digabung dan dicari ciri pokoknya. Ketiga, kategori yang ditemukan, kemudian dibubungkan dengan kategori yang lain sehingga melahirkan proporsisi tertentu. Keempat, ditemukanya proposisi, kemudian dibangun suatu kesimpulan pemahaman yang mengarahkan pada suatu kesimpulan penelitian.

\section{HASIL DAN PEMBAHASAN}

\section{a. Karakteristik}

Hasil penelitian ini menemukan 7 orang informan yaitu kategori anak yang mengalami perundungan akibat memiliki anggota keluarga disabilitas ganda dan masih bersekolah di SLBG Rawinala. Disabilitas ganda yang dimaksud disini adalah seseorang yang memiliki disabilitas majemuk (lebih dari satu disabilitas) dan utamanya pada mata. Karakteristik disabilitas ganda yang menjadi sibling informan adalah orang disabilitas yang memiliki gangguan utama pada mata ditambah dengan 4 kemajemukan lainnya antara lain gangguan pendengaran, autis, cerebral palsy dan ganguan mental. Karakteristik infomarman diketahui $60 \%$ berjenis kelamin lakilaki dengan usia SMP yaitu berkisar 12- 15 tahun, selebihnya berjenis kelamin perempuan dengan jenjang penddikan setara dengan SMU/SMK pada umur 16-18 tahun. Berdasarakan tempat tinggal infoman, $80 \%$ tinggal di wilayah padat penduduk dan $20 \%$ lainnya tinggal di perumahan cluster elite. Kedudukan dalam urutan struktur keluarga, infoman yang diteliti $60 \%$ merupakan kakak dan $40 \%$ adik dari sibling dengan disabilitas ganda yang tinggal dalam 1 rumah.

\section{b. Bentuk Perundungan}

Andrew (1984) mengungkapkan dalam bukunya Practical approaches to bullying bahwa penggunaan bahasa verbal yang bertujuan untuk menyakiti hati orang lain dapat dikatakan sebagai perundungan verbal. Pada bukunya, Andrew juga memberikan penegasan bahwa perundungan verbal memiliki kesamaan dampak dengan perundungan fisik karena dapat menimbulkan luka yang tidak terlihat namun sangat membekas di hati seseorang. Bentuk-bentuk perundungan yang dialami oleh infoman adalah:

1. Perundungan verbal. Perundungan verbal dinyatakan hampir sebagaian besar informan mengalami perundungan jenis ini. Bentuk yang dinyatakan sering diterima oleh infoman adalah berupa sindiran, perkataan yang jelek, berbisik- bisik, menertawakan, melemahkan, ejekan, membicarakan kejelekan yang mengarah pada keterbatasan yang dimiliki oleh siblingnya. Perkataan yang muncul seperti : " dasar kamu keturunan orang gila" ( wawancara El, 12 tahun), "jangan dekat-dekat nanti ketularaan buta kayak adeknya ," (wawancara EM, 13 tahun)," saya sering diejek kalo jajan, katanya nanti bisa ngeces (keluar air liur terus) seperti yang dialami kakak saya," (wawancara DS, 12 tahun)," ngeri ah muka adek lu, matanya ga da, serem kayak setan hidup," ( wawancara DS,15 tahun), pasti ada yang nyantet, kakak kamu dijadikan tumbal ya, kok tingkahnya aneh (wawncara TL, 16). Perundungan verbal banyak terjadi di lingkungan rumah dimana infoman tinggal yaitu di wilayah perumahan padat penduduk. Sebagain besar, aktor yang melakukan perundungan adalah teman sebaya yang tinggal di lingkungan rumah dan bukan di lingkungan sekolah. Informan mengakui, sebagian besar teman sekolah tidak mengetahui jika informan memiliki sibling penyandang disabilitas ganda. Peluang untuk bertemu dengan teman sekolah ke rumah, sengaja dihindari oleh infoman, misalkan menghindari belajar kelompok bersama dan main bersama agar tidak diketahui oleh teman-temanya atas keberadaan sibling. Meskipun ada beberapa teman sekolah yang mengetahui keberadaan sibling infoman, mereka kebanyakan bertanya tentang penyakit yang diderita oleh siblingnya. Pada penelitian ini, tidak ditemukan adanya perundungan fisik yang terjadi pada informan diakibatkan karena keadaan siblingnya. Namun demikian, penelitian ini menemukan bentuk http://ejurnal.binawakya.or.id/index.php/MBI 
perundungan verbal yang muncul justru dari keluarga inti dan keluarga besar khususnya kepada anak yang struktur kedudukannya sebagai kakak dari sibling penyandang disabilitas ganda. Bentuk perundungan yang sering diterima misalkan, ancaman agar tidak meningglakan sibliningnya ketika dwasa nanti, mendoktrin agar lebih mandiri, lebih kuat dan lebih bisa mengayomi, karena keadaan siblingnya yang tidak bisa diharapkan lagi. Meletakkan harapan tinggi pada pendidikan dan karier serta menempatkan menjadi pengganti orangtua, teman dalam memberikan pendampingan bagi suadara kandungnya yang disbiliatas menjadi beban tersendiri anak yang memiliki saudara kandung disabilitas. Harapan keluarga sadar atau tidak menjadi tekanan tersendiri yang membuat saudara kandung normal dalam posisi dilematis dan tidak menguntungkan.

2. Perundungan non verbal. Perilaku perundungan non verbal di tandai dengan ditampilkannya perilaku dengan menujukkan ekspresi muka yang "berbeda" atas keberadaan seseorang yang memiliki sibling disabilitas ganda. Ekspresi muka yang sering diterima antara lain seperti sikap mencibir, bersikap sinis, menunjukkan gesture tubuh menghindar dan takut. Hal ini terjadi jika informan melakukan aktifitas bersama di tempat umum bersama dengan siblingnya yang penyandang disabilitas. Tempat umum tersebut antara lain taman bermain, tempat bermain umum, mall, warung, lingkungan rumah. "Jika saya ke minimarket dengan membawa adik (disbilitas ganda), orangorang sekitar melihat saya dengan pandangan yang aneh" (wawancara JK, 18). "Saya pernah ke warung, dan menyerahkan uang, namun ibu warung meminta saya meletakkan di meja, dia tidak mau menerima langsung karena melihat saya membawa adik saya yang terus mengeluarkan air liur. "Saya merasa tersinggung saat itu." ( Wawancara TL, 17). Penelitian ini menemukan bahwa aktor perundungan non verbal banyak dilakukan oleh orang yang lebih dewasa.

3. Perundungan di dunia maya. Pada penelitian ini, juga diketahuia bahwa $20 \%$ http://ejurnal.binawakya.or.id/index.php/MBI informan pernah mengalami perundungan maya, melalui komentar nitizen yang disampaikan di laman twitter dan Instagram milik infoman. Seperti diungkapkan informan, netizen yang memberikan komen negative berasal teman yang tidak dikenali. "fotonya aneh, semua pada senyum kok ada yang malah melet" (wawancara JK, 12). "Mendingan tidak usah diajak foto, daraipada ngrusak pemandangan" (Wawancara DS, 16). Hal tersebut yang menyebabkan infoman enggan mengapload foto kebersamaam dengan siblingnya dan memilih menseleksi foto yang akan di upload ke medsos, untuk untuk menghindari komen yang negative. Reaksi infoman ketika mendapatkan perundungan adalah mengabaikan, diam, pura-pura tidak mendengar , menangis, dan tidak membalas komentar negative jika di medsos. Hal itu dilakukan karena infoman pada saatu kondisi harus melindungi siblingnya dan tidak mau memperpanjang masalah. Beberapa orang tua menerima aduan tentang peristriwa perundungan yang menimpa anaknya, dan kebanyakan mereka memberikan saran agar tidak memperpanjang masalah dengan terus menerus memperdulikan perkataan orang lain. Orang tua justru menyarankan anaknya untuk lebih baik diam, lebih kuat, belajar menerima keadaana sibling dan meninggalkan orangnya yang tidak memberikan respek atas keadaan saudara kandungnya yang disabilitas. Penelitian ini juga menemukan bahwa orang tua memilih menguatkan psikologis anak dengan menyakinkan bahwa ada balasan Tuhan atas perilaku buruk atas kejadianya yang menimpa anaknya mengalami perundungan akibat keadaan siblingnya.

\section{c. Dampak perundungan}

Dampak yang terjadi pada anak yang memiliki sibling disabilitas ganda terdiri dari 2 besaran yaitu dampak internal dan dampak ekternal yang dapat dijelaskaan antara lain:

a. Dampak internal. Dampak internal mengacu pada dampak yang lebih banyak terjadi pada diri korban perundungan yang dapat mempengaruhi perilaku korban dengan relasi yang dimunculkan baik kepada siblingnya,

Vol.15 No.5 Desember 2020 
keluarga maupun masyarakat umum. Anak yang mengalami perundungan akibat memiliki saudara kandung yang disabilitas ganda memiliki kecenderungan membatasi kebersamaan dengan siblingnya di dunia luar.

Dampak secara sosial, anak membatasi interaksi sibilingnya dengan dunia luar. Perilaku yang dimunculkan adalah anak tidak mau mengajak saudara kandungnya yang disbilitas ganda untuk membawa jalan- jalan keluar rumah, enggan membawa ke tempat ibadah (sholat jumat bersama) dan area publik, menjauh dari keramaian, enggan berjalan bersama, membatasi aktifitas yang dilakukan bersama dan menghindari untuk diminta menjaga siblingnya jika berada di luar rumah. Interaksi antara antar sibling menjadi terbatas di depan umum dan nampak kerenggangan antar sibiling.

Dampak secara psikologis, saudara kandung yang mengalami perundungan diketahui menjadi malu, ada perasaan membenci, muncul perasaan terabaikan, iri dan merasa hidupnnya menjadi tidak bebas akibat keberadaan siblingnya dengan disabilitas ganda. Selain itu adanya perasaan dilematis, seringkali dirasakan yaitu adanya keingginan untuk memberikan perlindungan kepada saudara kandungnya yang disabilitas, namun di sisi lainya korban merasa mendapatkan dampak negative dan juga memerlukan perlindungan. Adanya perasaan malu dan rendah diri jika bersama, memunculkan perubahan kualitas dna intensitas interaksi dengan siblingnya yatitu memilih manjauh dan menghindar untuk bersama sama agar tidak menjadi pusat perhatian orang.

Dampak psikologis lainnya yang muncul adalah perasaan malu menjadi bagian keluarga dan memiliki kecenderungan menyembunyikan status atau keadaan fisik siblingnya. Penelitian ini juga mengungkapkan bahwa adanya dampak positif yang terjadi yaitu adanya perasaan lebih menerima dan menyayangi antar sibling. Hubungan saling menyanyangi dan melindungi ini juga ditanamkan poleh oaring tua agar mereka tetap bisa saling menopang, mendukung dan menguatkan satu dengan lainnya. Penelitian ini belum menujukkan munculnya gejala traumatis

Vol.15 No.5 Desember 2020 yang dialami oleh anak akibat perundungan yang telah diterima akibat kondisi sibling dengan disabilitas ganda yang dapat menyebabkan depresi atau tekanan mental lainnya.

b. Dampak eksternal. Dampak ini lebih disebabkan adanya stigma/labeling yang dilekatkan kepada anak sebagai bagian anggota keluarga yang memiliki saudara dengan disabilitas ganda. Stigma yang dilekatkan lebih banyak berhubungan dengan adanya paradigma lama yang mempercayai bahwa disabilitas terutama yang ganda terjadi karena adanya kutukan, atau bagaian dari hal mistik yang dilakukan anggota kelaurga di masa lalu, sehingga menimbulkan dampak pada seluruh anggota keluarga.

Stigma tersebut disadarai atau tidak membawa dampak pada anak yaitu adanya kecenderungan tidak percaya diri dalam menjalin pertemanan dengan orang lain. Penelitian ini juga mengungkapkan adanya perasaan malu dalam menjalin hubungan pertemanan yang lebih dekat, karena adanya penolakan dari lawan jenis untuk menjadi teman dekat karena diketahui memiliki anggota keluarga yang disabilitas ganda. Hal ini akan menjadi kejadian yang sulit dilupakan oleh korban. Situasi yang tidak mudah juga diceritakan oleh korban atas perundungan yang mungkin akan terus terjadi karena keberadaan siblingnya.

Tekanan emosional sering tak terhindarkan atas stigma keluarga penyandang disabilitas, yaitu adanya perilaku menutup diri, dan rendah diri untuk menjalin relasi dengan orang lain. Keberadaan saudara kandung dengan disabilitas ganda membuat korban merasa tersisih dari pergaulan teman sebaya. Teman sebaya sering menanyakan penyebab saudara kandung yang "aneh" secara fisik dan menghubungkannya dengan hal lain yang tidak membuat nyaman.

\section{c. Sikap keluarga terhadap anak yang mengalami perundungan}

Penelitian ini menujukkan bahwa sikap yang dilakukan orang tua adalah memberikan dukungan dan menguatkan mentalitas anak. Diakui oleh orang tua bahwa beberadaan anak dengan disabilitas ganda seringkali menyita http://ejurnal.binawakya.or.id/index.php/MBI 
perhatian dan memerlukan perhatian khusus dari seluruh keluarga. Hal ini menyebabkan orangtua mengabaikan kebutuhana anak non disabilitas karenan sudah dianggap mampu mandiri dan tidak perhatian khusus dibandingkan dengan sibling disabilitas ganda. Menjaga mental anak yang memiliki pengalaman mengalami perundungan sebagai akibat adanya kehadiran saudara kandung yang memiliki disabilitas menjadi konsen tersendiri bagi keluarga. Hal ini menjadi penting karena anak akan hidup dalam jangka waktu lama dengan saudara kandungnya dan perlu dibangun interaksi yang baik antara keduanya. Penelitian ini juga mengungkapkan bahwa harapan untuk menjadi pelindung, penganyom, dan kebanggaan keluarga , menjadi beban tersendiri untuk anak-anak yang memiliki sibling disabilitas ganda. Mereka ditempatkan sebagai melindungi saudara kandungnya yang disabilitas ganda dan harus mampu menjaga, memberikan kasih sayang, menemani dan juga mengalah atas keberadaan sibilingnya dengan kekhususan.

\section{PENUTUP}

\section{Kesimpulan}

Dari hasil penelitian di atas, diperoleh hasil bahwa: Penelitian ini juga menggambarkan kerentanaan anak yang mengalami perundungan. Kerentanan ini diakibatkan adanya tekanan dari dalam dirinya yaitu rasa malu, perasaan tidak nyaman, tersisih dan tekanan yang berasal dari luar lingkungan keluarga Kehadiran sibling dengan disabilitas ganda dalam kelaurga memungkinan suadara lain (non disbilitas) mengalami kerentanan ganda sehingga memerlukan dukungan penuh dari semua pihak terutama keluarga, lingkungan, teman sebaya, peran pekerja sosial dan juga pihak-pihak yang dapat membantu perundungan yang terjadi pada anak. Perlu ada penelitian lanjutan terkaita dengan bentuk penguatan kepada anak yang mengalami perundungan baik kepada individu, penguatan peran prang tua, peran lingkungan dan juga sekolah. Perlunya sosialiasi terkait dengan dampak bully yang terlakit dengan relasi anak disbilitas dan non disabilitas. Pentingnya http://ejurnal.binawakya.or.id/index.php/MBI

\section{Open Journal Systems}

memberikan perhatian yang seimbang anak dengan disabilitas dan non disabilitas menjadi penting dipertimbangkan oleh orangtua, karena keduanya memerlukan perhatian yang sama.

\section{DAFTAR PUSATAKA}

[1] Andrew, J. Practical approaches to bullying. London: David Fulton. (1984).

[2] Buhrmester. D \& Furman, W. Perceptions of Sibling Relationships During Middle Childhood and Adolescence, Child Development, 1990, 4.

[3] Fifi Nurmaningtyas \& Moh. Reza, "Sibling Rivalry pada Anak ASD (Autistic Spectrum Disorder) dan Saudara Kandungnya (Studi Kasus di Sekolah At-Taqwa Surabaya)", Jurnal Character, Vol. 01 N0. 02, UNESA, Surabaya, 2013, 1.

[4] Hurlock, Elisabeth. Psikologi Perkembangan: Suatu Pendekatan Sepanjang Rentang Kehidupan (Edisi 5). Jakarta: Erlangga, 1994

[5] Hartinah, Siti.. Pengembangan Peserta Didik. Bandung: PT Rafika Aditama. 2010

[6] Johnson, D.W, Johnson. F. Joining Together. Group Theory and Group Skill. Fourth Edition. Englewood Cliffts. Prentice Hall Inc. 1991.

[7] Maria Elvira De Caroli \& Elisabetta Sagone, "Siblings and Disability: A study on social attitudes toward disabled brothers and sisters", Procedia Social and Behavioral Sciences, Department of Educational Sciences, 95124 Catania, Italy, 2012, 1.

[8] Nago Tejena \& Tience Debora Valentina, "Sibling Rivalry Antara Anak Dengan Mild Intellectual Disability Dan Saudara Kandung", Jurnal Psikologi Universitas Udayana, Vol. 2, No. 2, 129-137, 2015, 130.

[9] Pramadani Arti, Pemaknaan Sibling Relationship pada Individu Normal dengan Saudara Penyandang Disabilitas, Skripsi, Fakultas Psikologi Universitas Gadjah Mada, Yogyakarta, 2016, 1

[10]Sevira, Hubungan antara Sibbling Relationship dengan Motivasi Intrinsic pada

Vol.15 No.5 Desember 2020 
Anak-Anak Usia 11 Tahun, Fakultas

Psikologi, Universitas Padjadjaran, 2.

[11] Stefany Widya Ayu Wulandari, Hubungan

Persaudaraan (Sibling Relationship) pada

Anak Kembar Berjenis Kelamin Sama, Skripsi, Fakultas Psikologi Universitas

Kristen Satya Wacana, Salatiga, 2014, 4-6

[12] Shanty Theresia Naibaho, Evany Victoriana, $\&$ N. Talitha Tjoeng, "Studi Deskriptif mengenai Sibling Relationship pada Remaja dengan Saudara Spektrum Autisme”, Jurnal Humanitas, Fakultas Psikologi Universitas Kristen Maranatha, Bandung, Vol. 1, No. 2, Agustus 2017, 104.

[13] Sakroni, S. Peran pekerja sosial sekolah dalam menangani perundungan di sekolahsekolah di bandung. Sosio Konsepsia, 9(1), 2020, 77-98.

[14] Tjahjono, Herry. Matinya Empati Sosial (Opini). Jakarta: Harian Kompas. 2017

[15]Ribka Mutiara Simatupang \& Rr. Muryantinah Mulyo Handayani, "Pola Relasi Saudara pada Remaja yang Memiliki Saudara dengan Gangguan Spektrum Autisme", Jurnal Psikologi Klinis dan Kesehatan Mental, Vol. 04, No.01, April 2015, 4498-4

[16]Ribka Mutiara Simatupang \& Rr. Muryantinah Mulyo Handayani, "Pola Relasi Saudara pada Remaja yang Memiliki Saudara dengan Gangguan Spektrum Autisme", Jurnal Psikologi Klinis dan Kesehatan Mental, Vol. 04, No.01, April 2015, 3-5. 